\title{
Technological prospection of the biological activities of Plectranthus amboinicus (Loureiro) Sprengel: an integrative review
}

Prospeç̧ão tecnológica das atividades biológicas de Plectranthus amboinicus (Loureiro) Sprengel: uma revisão integrativa

Prospección tecnológica de las actividades biológicas de Plectranthus amboinicus (Loureiro) Sprengel: una revisión integradora

Elizabeth Regina de Castro Borba ORCID: https://orcid.org/0000-0002-0613-3977

Universidade Federal do Maranhão, Brazil E-mail: elizabeth.castro@ufma.br

Haymê dos Santos Ferreira

ORCID: https://orcid.org/0000-0002-9119-8256

Universidade Federal do Maranhão, Brazil E-mail: haymeparle01@ outlook.com

Thiago Castro Mubárack

ORCID: https://orcid.org/0000-0002-6705-8288

Universidade Federal do Maranhão, Brazil E-mail: thiagomubarack@gmail.com

Tássio Rômulo Silva Araújo Luz ORCID: https://orcid.org/0000-0001-7968-0915

Universidade Federal do Maranhão, Brazil

E-mail: tassioromulo@gmail.com

Daniella Patrícia Brandão Silveira ORCID: https://orcid.org/0000-0001-6520-5312

Universidade Federal do Maranhão, Brazil

E-mail: daniellapbsilveira@hotmail.com

Ana Zélia Silva

ORCID: https://orcid.org/0000-0001-6565-2868

Universidade Federal do Maranhão, Brazil E-mail: ana.zs@ufma.br

Patrícia de Maria Silva Figueiredo ORCID: https://orcid.org/0000-0002-0087-9524

Universidade Federal do Maranhão, Brazil

E-mail: figueiredo.patricia@ufma.br

Odair dos Santos Monteiro

ORCID: https://orcid.org/0000-0003-0607-1531

Universidade Federal do Maranhão, Brazil E-mail: odair.sm@ufma.br

Yan Michel Lopes Fernandes

ORCID: https://orcid.org/0000-0002-5464-9660 Universidade Estadual Paulista “Júlio Mesquita Filho", Brazil E-mail: yfernandes04@gmail.com

Crisálida Machado Vilanova

ORCID: https://orcid.org/0000-0001-8502-1625 Universidade Federal do Maranhão, Brazil

E-mail: crisalida.vilanova@ufma.br

Denise Fernandes Coutinho

ORCID: https://orcid.org/0000-0002-5665-9280 Universidade Federal do Maranhão, Brazil E-mail: denise.coutinho@ufma.br

\begin{abstract}
Plectranthus amboinicus (Loureiro) Sprengel is popularly known as malvariço or indian borage. This paper carries out the technological prospecting of this species with an emphasis on its biological activities. The research consisted of an integrative literature review based on information collected from patent and electronic databases. Initially, 3019 results were obtained, which, after the screening, selection and analysis process, resulted in 55 articles and 48 patent documents. It was found that $77.08 \%(n=37)$ of patent deposits refer to obtaining or improving the process and $22.92 \%(\mathrm{n}=11)$ to the finished product related to the following indications: wound healing, mainly in diabetics,
\end{abstract}


followed by treatment of rheumatoid arthritis, hepatocellular carcinomas, breast cancer and melanoma, treatment for acne caused by $P$. acnes, $S$. aureus and $P$. aeruginosa, oral cavity cleansing agent, treatment for osteoporosis, nutraceutical composition for lactation and insect repellent. In the databases of scientific articles, 55 documents were selected, proving the following actions: antimicrobial, antioxidant, anticarcinogenic, anti-inflammatory, diuretic, nephroprotective, larvicide, analgesic, veterinary food additive, anti-leishmania, antipsoriasis, antidiarrheal, antidiabetic, hepatoprotective and anthelmintic. The scientific studies analyzed reaffirm other actions reported in popular use, but which are not described in the patent processes. Therefore, there are many proven biological properties of $P$. amboinicus that should be further explored and exploited in the pharmaceutical, cosmetic and food sectors in order to generate new products and patents.

Keywords: Plectranthus amboinicus (Loureiro) Sprengel; Prospecting; Malvariço; Indian Borage; Patents.

\section{Resumo}

Plectranthus amboinicus (Loureiro) Sprengel é popularmente conhecida como malvariço ou indian borage. Esta pesquisa realiza a prospecção tecnológica desta espécie com ênfase em suas atividades biológicas. A pesquisa consistiu em uma revisão integrativa de literatura baseada em informações coletadas em bancos de dados de patentes e bases de dados eletrônicas. Obteve-se inicialmente 3019 arquivos, que após processo de triagem, seleção e análise, resultaram em 55 artigos e 48 documentos de patentes. Constatou-se que $77.08 \%(n=37)$ dos depósitos de patentes referem-se a obtenção ou melhoramento de processo e $22.92 \%(n=11)$ à produto acabado relacionados as seguintes indicações: cicatrização de ferimentos principalmente em pacientes diabéticos, seguido de tratamento de artrite reumatoide, carcinomas hepatocelular, câncer de mama e melanoma, tratamento para acne causada por $P$. acnes, $S$. aureus e $P$. aeruginosa, agente de limpeza da cavidade oral, tratamento para osteoporose, composição nutracêutica para lactação e repelente de insetos. Nas bases de dados de artigos científicos selecionaram-se 55 documentos, comprovando-se as seguintes ações: antimicrobiana, antioxidante, anticarcinogênica, antiinflamatória, diurética, nefroprotetora, larvicida, analgésica, aditivo alimentar de uso veterinário, anti-leishmania, antipsoríase, antidiarreica, antidiabética, hepatoprotetora e antihelmíntica. Os estudos científicos analisados reafirmam outras ações relatadas no uso popular, mas que não estão descritas nos processos de patentes. Portanto, existem muitas propriedades biológicas comprovadas de $P$. amboinicus que devem ser mais exploradas e aproveitadas nas áreas farmacêutica, de cosméticos e de alimentos visando a geração de novos produtos e patentes.

Palavras-chave: Plectranthus amboinicus (Loureiro) Sprengel; Prospecção; Malvariço; Indian Borage; Patentes.

\section{Resumen}

Plectranthus amboinicus (Loureiro) Sprengel se conoce popularmente como malvariço o borraja india. Esta investigación realiza la prospección tecnológica de esta especie con énfasis en sus actividades biológicas. La investigación consistió en una revisión integradora de la literatura basada en información recopilada de bases de datos de patentes y bases de datos eletrónicas. Inicialmente se obtuvieron 3019 expedientes que, luego del proceso de cribado, selección y análisis dieron como resultado 55 artículos y 48 documentos de patente. Se encontró que el $77.08 \%(\mathrm{n}=37)$ de los depósitos de patentes se refieren a la obtención o mejora del proceso y el $22.92 \%(\mathrm{n}=11)$ al producto terminado con las siguientes indicaciones: cicatrización de heridas principalmente en pacientes diabéticos, seguida de tratamiento de artritis reumatoide, carcinomas hepatocelulares, cáncer de mama y melanoma, tratamiento del acne por $P$. acnes, $S$. aureus y $P$. aeruginosa, agente limpiador de la cavidad oral, tratamiento para la osteoporosis, composición nutracéutica para la lactancia y repelente de insectos. En las bases de datos de artículos científicos se seleccionaron 55 documentos, comprobando las siguientes acciones: antimicrobiano, antioxidante, anticancerígeno, antiinflamatório, diurético, nefroprotector, larvicida, analgésico, aditivo alimentario veterinario, antileishmanial, antipsoriasis, antidiarreico, antidiabético, hepatoprotector y antihelmíntico. Los estudios científicos analizados reafirman otras acciones reportadas de uso popular que no están descritas en los procesos de patente. Por lo tanto, existen muchas propiedades biológicas comprobadas de $P$. amboinicus que deberían explorarse y explotarse más a fondo en los sectores farmacéutico, cosmético y alimentrio para generar nuevos productos y patentes.

Palabras clave: Plectranthus amboinicus (Loureiro) Sprengel; Prospección; Malvariço; Indian Borage; Patentes.

\section{Introduction}

Biotechnology research has evolved quickly and safely in the production of information, which can be seen by the growing development of new processes and products. Technological prospecting studies have shown a way of schematizing and informing technoscientific advances, which has narrowed the distance between invention and commercialization of products (Amparo et al., 2012; Caruso \& Tigre, 2004; Oliveira \& Quental, 2012).

The possibility of identifying and obtaining compounds with varied pharmacological actions has stimulated research on medicinal plants (Souto-Maior et al., 2011). Species of the genus Plectranthus (Lamiaceae) are found on four continents: Africa, America, Oceania, and Asia (Arumugam et al., 2016; Ruan et al., 2019). 
Plectranthus amboinicus (Loureiro) Sprengel, popularly known as malvariço or indian borage, is a herbaceous plant, up to one meter long, succulent with a brittle stem, oval leaves with thick apex, jagged edges and a thick petiole with a sharp tip. Phytochemical studies have described the existence of 76 volatile and 30 non-volatile compounds that belong to different classes of constituents, such as monoterpenes, diterpenes, triterpenes, sesquiterpenes, phenolics, flavonoids, esters, alcohols and aldehydes, with diterpenoids, triterpenoids and essential oils (OEs) being the most common metabolites. Some noticeable pharmacological actions of this plant are: antimicrobial, anti-inflammatory, antitumor, healing, antiepileptic, and analgesic activities (Arumugam et al., 2016; Ruan et al., 2019).

The low cost and therapeutic benefits presented have led part of the population to use natural products. New products made from medicinal plants originated in popular knowledge and were later scientifically proven. The systematization of records of the use of this species aims to stimulate access to innovative research and the generation of patents through a selection of bioassays that exhibited biological effects in a simple, sensitive and safe way.

This research sought to identify scientific and technological advances in processes and/or products associated with biological properties, in order to create an updated information source that disseminates the evidence of the pharmacological action. The idea of conducting a logical and rational analysis of the existing data in patent databases and academic research reveals the current panorama of the world market and leads to a compendium of relevant information on the main lines of research developed with P. amboinicus.

\section{Methodology}

The research consisted of an integrative literature review that seeks the synthesis of knowledge and the incorporation of the applicability of the results of significant studies in practice (Silveira, 2005; Souza et al., 2010). It was based on information collected from databases of patents and scientific articles. The question that guided the study was: Are there scientifically proven therapeutic actions by Plectranthus amboinicus that have not yet been patented?

\subsection{Data sources}

Scientific research was carried out in four electronic databases: SCIELO (Scientific Electronic Library Online), Google Scholar, PUBMED (National Library of Medicine of the United States, National Institutes of Health) and CAPES Portal (Coordination for the Improvement of Higher Education Personnel). The technological prospection was also carried out on four patent databases: USPTO (United States Patent and Trademark Office), WIPO (World Intellectual Property Organization), ESPACENET, and INPI (National Institute of Industrial Property). The search was performed by combining two criteria: i) descriptors and ii) search for international patent classification - IPC - codes (prospecting). Scientific names were used for titles and abstracts, with or without the Boolean operator "AND". The descriptors used in the study are described in Figure 1. 
Figure 1. Heteronyms isolated or associated with Boolean operators.

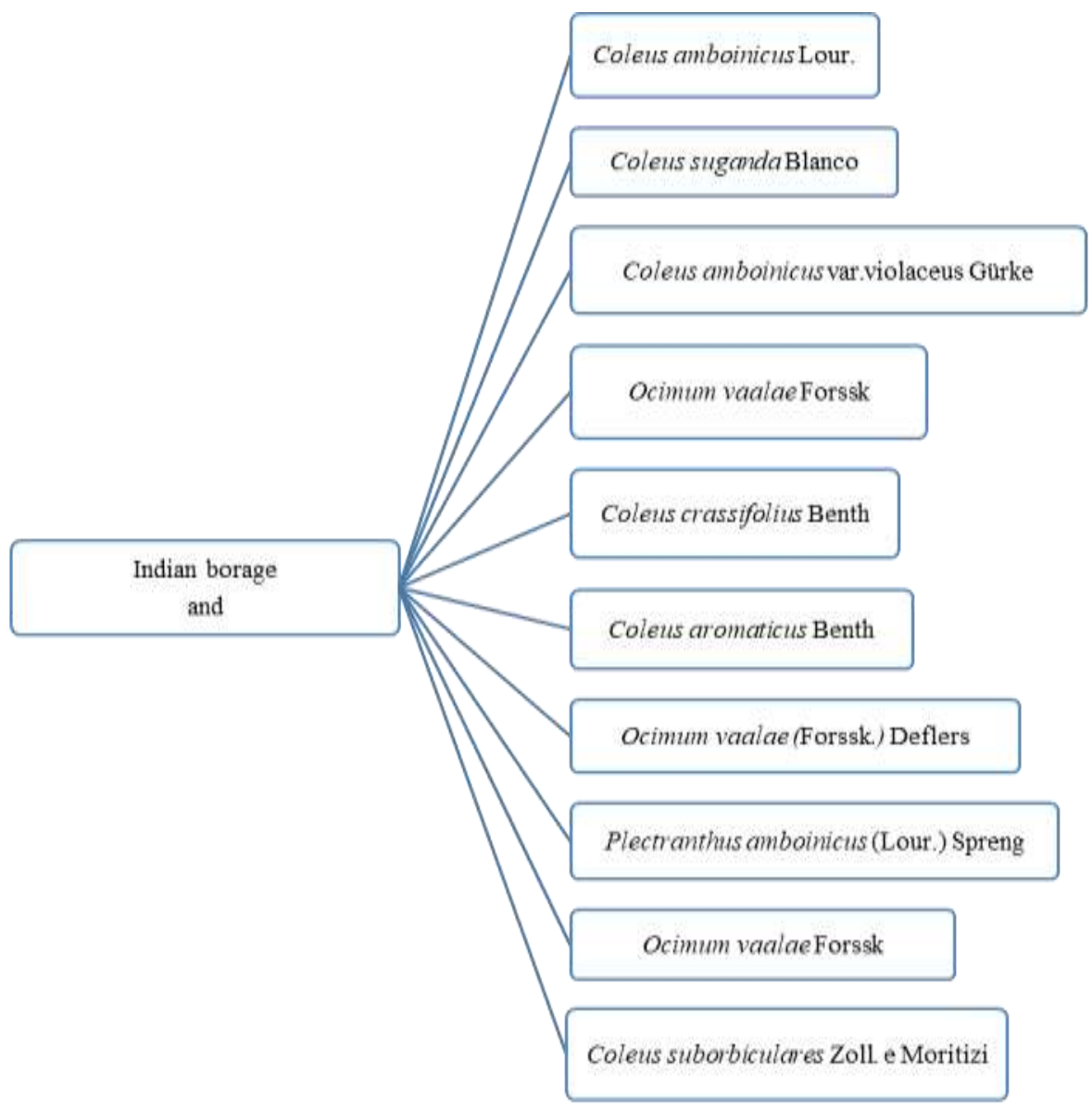

Source: Authors (2021).

\subsection{Selection criteria}

The selection criteria were based on the inclusion and non-inclusion criteria established by the researchers. Among the 3019 files found, 154 documents (83 articles and 71 patents) were selected for reading in full. The inclusion criterion covered materials that addressed: technological applications, therapeutic uses, formulations developed and the parts used of this species. The non-inclusion criteria were: year of publication of the articles, duplication in the patent databases and academic research consulted, articles and/or patents whose focus was not directed to biological uses and properties, development of formulation or technologies involving this species.

During the research with heteronyms of the species P. amboinicus (taken from the site: reflora.jbrj.gov.br) and the Boolean operator "AND" plus "Indian Borage", the files were selected and quantified, excluding those that did not correspond to the criteria. Review articles, conference abstracts and articles that studied their effects associated with other plants or other properties of the same were excluded. The selection and quantification of the data obtained in each analysis process can be seen in Figure 2. 
Figure 2. Process of sorting and selecting data in patent and academic research databases.

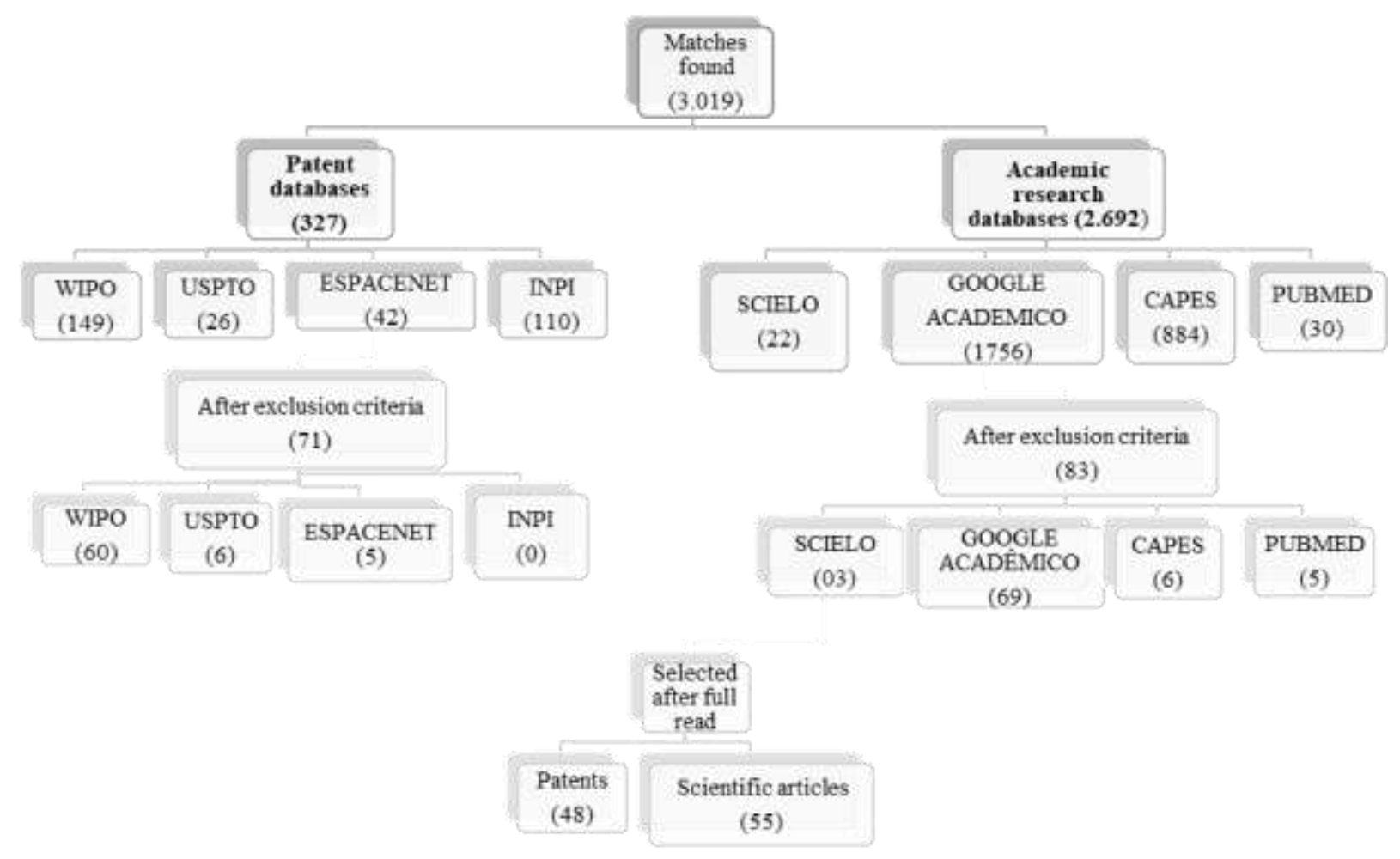

( ): represents the number of selected files. Souce: Authors (2021).

\subsection{Data analysis}

Data collection and analysis was carried out in January 2020, through a selection of scientific articles published in the last 10 years (from January 2010 to December 2019) and all published patents found in the patent databases, without temporal (1976 to 2019) or language delimitations, to discuss and cross-check the data found. The list of relevant article references to the research was verified and, then, they were subjected to an exploratory and selective reading to identify data related to the proposed theme according to the objective of the study.

The first step was to analyze the titles and read the abstracts. The files that met the inclusion criteria were read in full and then selected according to the objective of this work. Some aspects that guided the analysis of the archives were the year of publication, research articles and essential observations on the proposed theme. Regarding the analysis of the patents, the criteria used to determine compliance with the research topic were: title, abstract, documentation and patent number. The files that had the scientific or popular name of the plant in the title and/or abstract were selected for further analysis of prospection by classification, year and country.

The extracted data were organized in a Microsoft@ Excel spreadsheet. After corrections, the information was exported to the Statistical Package for the Social Sciences (SPSS) software, version 26.0, where statistical processing was performed. To characterize the sample, descriptive statistics were performed using simple frequency.

\section{Results and Discussion}

The data selection process (scientific articles and data from patent databases) initially generated 3019 files matching the chosen descriptors and study period, including files duplicated by the research sources. Of the 3019 files retrieved, 2692 
results corresponded to scientific articles and 327 corresponded to results in patent databases. The quantification of these data can be observed in Table 1.

After selection and analysis (titles and abstracts), 83 scientific articles and 71 patents issued (154 documents) were chosen to be read in full. For a better selection of data, a search for therapeutic indications was carried out in patent database and academic research, with a subsequent reading in full of the selected results. After a critical review of the articles, 48 patent documents and 55 scientific publications were selected for further analysis and discussion.

The search for scientific articles in the chosen electronic databases provided 2692 initial results, most of them in Google Scholar $(n=1756)$, followed by the Portal of CAPES $(n=884)$, PUBMED $(n=30)$ and SCIELO $(n=22)$. The search in the patent databases returned 327 results, most of them found in WIPO $(n=149)$, followed by INPI $(n=110)$, ESPACENET $(n=42)$ and USPTO $(n=26)$.

After the initial results obtained from the patent databases $(n=327)$ were filtered by the inclusion / exclusion criteria, 57 issued patents were returned. It was observed, however, that 05 of the USPTO results and 03 of ESPACENET results were also filed at WIPO and 1 result was filed. After the final selection, 48 issued patents were chosen for final analysis, all extracted from WIPO.

The databases were searched and the collected date were crossed. Some differences were observed in the results obtained with the use of popular synonyms and their applications in the formulations developed in the selected works (Table 1). 
Table 1. Initial quantification of data obtained with the selected descriptors.

\begin{tabular}{|c|c|c|c|c|c|c|c|c|}
\hline Descriptors & WIPO & USPTO & INPI & CAPES & ESPACENET & $\begin{array}{l}\text { GOOGLE } \\
\text { SCHOLAR }\end{array}$ & PUBMED & SCIELO \\
\hline C.amboinicus Lour & 43 & 7 & 0 & 205 & 12 & 973 & 02 & 2 \\
\hline $\begin{array}{l}\text { C. amboinicus Lour And } \\
\text { Indian Borage }\end{array}$ & 26 & 0 & 0 & 277 & 13 & 424 & 0 & 0 \\
\hline Ocimum vaalae Forssk & 0 & 0 & 04 & 01 & 0 & 0 & 02 & 0 \\
\hline $\begin{array}{l}\text { Ocimum vaalae Forssk. AND } \\
\text { Indian Borage }\end{array}$ & 0 & 0 & 0 & 0 & 0 & 0 & 02 & 0 \\
\hline $\begin{array}{l}\text { Coleus amboinicus } \\
\text { var.violaceus Gürke }\end{array}$ & 0 & 0 & 36 & 0 & 0 & 3 & 0 & 0 \\
\hline $\begin{array}{l}\text { Coleus amboinicus var. } \\
\text { Violaceus Gürke AND Indian } \\
\text { Borage }\end{array}$ & 0 & 0 & 36 & 0 & 0 & 0 & 0 & 0 \\
\hline $\begin{array}{l}\text { Coleus amboinicus } \\
\text { var.violaceus Gürke }\end{array}$ & 0 & 0 & 0 & 0 & 0 & 2 & 0 & 0 \\
\hline $\begin{array}{l}\text { Coleus amboinicus } \\
\text { var.violaceus Gürke AND } \\
\text { Indian Borage }\end{array}$ & 0 & 0 & 0 & 0 & 0 & 0 & 0 & 0 \\
\hline Coleus suganda Blanco & 03 & 0 & 0 & 03 & 01 & 269 & 0 & 0 \\
\hline $\begin{array}{l}\text { Coleus suganda Blanco AND } \\
\text { Indian Borage }\end{array}$ & 02 & 0 & 0 & 02 & 0 & 0 & 0 & 0 \\
\hline $\begin{array}{l}\text { Plectranthus amboinicus } \\
\text { (Lour.) Spreng }\end{array}$ & 50 & 2 & 02 & 205 & 0 & 12 & 22 & 20 \\
\hline $\begin{array}{l}\text { Plectranthus amboinicus } \\
\text { (Lour.) Spreng AND Indian } \\
\text { Borage }\end{array}$ & 11 & 3 & 0 & 31 & 0 & 9 & 02 & 0 \\
\hline Coleus carnosus Hassk. & 02 & 0 & 0 & 02 & 0 & 59 & 0 & 0 \\
\hline $\begin{array}{l}\text { Coleus carnosus Hassk. AND } \\
\text { Indian Borage }\end{array}$ & 02 & 0 & 0 & 01 & 0 & 6 & 0 & 0 \\
\hline $\begin{array}{l}\text { Coleus subfrutectosus } \\
\text { Summerh. }\end{array}$ & 0 & 0 & 0 & 01 & 0 & 2 & 0 & 0 \\
\hline $\begin{array}{l}\text { Coleus } \\
\text { subfrutectosus Summerh. } \\
\text { AND Indian Borage }\end{array}$ & 0 & 0 & 0 & 0 & 0 & 1 & 0 & 0 \\
\hline Coleus aromaticus Benth & 05 & 0 & 16 & 100 & 0 & 1 & 0 & 0 \\
\hline $\begin{array}{l}\text { Coleus aromaticus Benth. } \\
\text { AND Indian Borage }\end{array}$ & 02 & 0 & 0 & 23 & 0 & 0 & 0 & 0 \\
\hline Coleus crassifolius Benth & 02 & 0 & 0 & 01 & 16 & 0 & 0 & 0 \\
\hline $\begin{array}{l}\text { Coleus crassifolius Benth } \\
\text { AND Indian Borage }\end{array}$ & 01 & 0 & 0 & 20 & 0 & 0 & 0 & 0 \\
\hline $\begin{array}{l}\text { Coleus vaalae (Forssk.) } \\
\text { Deflers }\end{array}$ & 0 & 0 & 0 & 11 & 0 & 0 & 0 & 0 \\
\hline $\begin{array}{l}\text { Coleus vaalae (Forssk.) } \\
\text { Deflers AND Indian Borage }\end{array}$ & 0 & 4 & 0 & 01 & 0 & 0 & 0 & 0 \\
\hline $\begin{array}{l}\text { Coleus suborbicularis Zoll. \& } \\
\text { Moritzi }\end{array}$ & 0 & 0 & 0 & 01 & 0 & 0 & 0 & 0 \\
\hline $\begin{array}{l}\text { Coleus suborbicularis Zoll. \& } \\
\text { Moritzi AND Indian Borage }\end{array}$ & 0 & 10 & 0 & 0 & 0 & 0 & 0 & 0 \\
\hline TOTAL & 149 & 26 & 110 & 884 & 42 & 1756 & 30 & 22 \\
\hline
\end{tabular}

Source: Authors (2021).

\subsection{Prospecting of $P$. amboinicus in patent databases}

In this study, 48 patents issued until 2019 were identified, 11 patents (22.92\%) referring to finished product and 37 $(77.08 \%)$ to processes. It was observed that the majority of patents are from Japan $(n=14 / 29.17 \%)$, followed by the USA $(n=$ 08/6.67\%), South Korea $(n=07 / 14.58 \%)$, China $(n=06 / 12.50 \%)$, Europe $(n=05 / 10.42 \%)$, Canada $(n=04 / 8.33 \%)$, Malaysia $(\mathrm{n}=02 / 4.17 \%)$ and, finally, India $(\mathrm{n}=01 / 2.08 \%)$ and Russia $(\mathrm{n}=01 / 2.08 \%)$.

The analyzed patents on this species aimed at obtaining or improving processes or products with the following indications: wound healing, mainly in diabetic $(n=16 / 33.3 \%)$, treatment of rheumatoid arthritis $(n=14 / 29.1 \%)$, hepatocellular carcinoma, treatment of breast cancer and melanoma $(\mathrm{n}=08 / 16.7 \%)$, treatment for acne by $P$. acnes, S. aureus and $P$. 
aeruginosa $(n=03 / 6.3 \%)$, oral cavity cleaning agent $(n=02 / 4.2 \%)$, treatment for osteoporosis $(n=02 / 4.2 \%)$, nutraceutical composition for lactation $(n=02 / 4.2 \%)$ and insect repellent $(n=01 / 2 \%)$.

It was also detected in the prospecting research of this species a greater number of patents for isolated use classified in the A61K group (97.3\%) and one in the A61P group (2.7\%). Associated use patents are classified into the groups listed in Table 2.

Table 2. Patents of the species P. amboinicus (Loureiro) Sprengel classified by International Patent Classification (IPC)

\begin{tabular}{|c|c|c|}
\hline *Patents on isolated use & $\mathbf{N}$ & $\%$ \\
\hline A61K & 36 & 97.30 \\
\hline A61P & 1 & 2.70 \\
\hline$* *$ Patents on associated use & $\mathbf{N}$ & $\%$ \\
\hline $\mathrm{A} 61 \mathrm{~K}+\mathrm{A} 61 \mathrm{P}$ & 5 & 45.45 \\
\hline $\mathrm{A} 61 \mathrm{~K}+\mathrm{C} 11 \mathrm{D}$ & 2 & 18.18 \\
\hline $\mathrm{A} 61 \mathrm{~K}+\mathrm{A} 61 \mathrm{P}+\mathrm{A} 61 \mathrm{~F}$ & 2 & 18.18 \\
\hline $\mathrm{A} 61 \mathrm{~F}+\mathrm{A} 61 \mathrm{P}$ & 1 & 9.09 \\
\hline$A 61 K+A 61 Q+C 11 D+B 01 D$ & 1 & 9.09 \\
\hline
\end{tabular}

$* \mathrm{~A} 61 \mathrm{~K}=$ preparations for medical, dental, or toilet purposes; $\mathrm{A} 61 \mathrm{P}=$ specific therapeutic activity of chemical compounds

**A61F= Bandages, dressings or absorbent pads; A61Q - specific use of cosmetics or similar toilet preparations; B01D - separation processes; $\mathrm{C} 11 \mathrm{D}=$ detergent compositions

Source: Authors (2021).

From the data presented above, it can be seen that this species has been more studied in relation to the area of the A61K group (preparations for medical, dental or hygienic use), totaling 36 patents for isolated use (97.3\%). The A61K group appears in all 48 patents consulted when associated with other purposes (classifications), directing all studies to applications in humans, mainly for medical, dental or toilet purposes. The pharma industry's R\&D (Research and Development) sector in recent decades has shown only slight growth in innovation, while inventions and innovations in medical technologies have advanced more rapidly (Dutta et al., 2019).

According to the data obtained, the patents are mainly process patents, for human health purposes. These patents refer mainly to anti-inflammatory, healing and anti-tumor actions, especially with new extraction methods or improvement methods with a predominance of process patents.

\subsection{Prospecting in scientific article databases}

The search in academic research databases returned 83 documents, of which 55 were selected after reading in full. The following actions were identified: antimicrobial $(n=22)$, antioxidant $(n=12)$, anticarcinogenic $(n=8)$, anti-inflammatory $(n=7)$, diuretic and nephroprotective $(n=5)$, analgesic $(n=3)$, larvicide $(n=3)$, veterinary food additive $(n=02)$, antileishmania $(\mathrm{n}=2)$, antipsoriasis $(\mathrm{n}=1)$, antidiabetic $(\mathrm{n}=1)$, antidiarrheal $(\mathrm{n}=1)$, hepatoprotective $(\mathrm{n}=1)$ and anthelmintic $(n=1)$. It is noteworthy that of the 55 articles selected, 11 analyzed more than one pharmacological action. Nine of these files simultaneously investigated two pharmacological activities, one file made a study with three pharmacological actions (Bhatt et al., 2013) and the other document (El-hawary et al., 2012) analyzed five pharmacological actions. 


\subsubsection{Antimicrobial and antidiarrheal activities}

In twenty-two selected articles on antimicrobial activity, studies with extracts and OE extracted from the leaves were found. These studies confirmed its activity against gram negative bacteria: Enterobacter sp, E. coli, diarrheogenic Escherichia coli, Klebsiella pneumoniae, Pseudomonas aeruginosa, Salmonella sp, Shigella flexneri, Shigella sp. (Shigella bayedir), Vibrio sp., Yersinia enterocolitica and also against gram positive bacteria: Bacillus cereus, Bacillus subtilis, Enterococcus faecalis, Lactobacillus acidophilus, Methicillin resistant Staphylococcus aureus, Streptococcus mutans and Streptococcus pyogenes.

The hydroalcoholic extract showed satisfactory results against Bacillus subtilis, Pseudomonas aeruginosa, S. aureus, Shigella bayedir (Majee et al., 2013; Oliveira et al., 2013). Nanoparticles developed from the hydroalcoholic extract of had satisfactory results against: C. albicans, Enterococcus faecalis (Manojkanna et al., 2017), Lactobacillus and Streptococcus mutans (Manojkanna et al., 2019). In 2017, Sireesha et al. added information on the antibacterial activity of the ethanolic extract proving its action also against Mycobacterium tuberculosis.

Analyses with hydroalcoholic extract, carried out in other studies, also demonstrated activity against Klebsiella pneumoniae bacteria (Ismayil \& Nimila, 2019) with action attributed to the major carvacrol (Goncalves et al., 2012) and against Aspergillus niger and C. albicans type fungi (El-hawary et al., 2012; Majee et al., 2013; Sivaranjani, 2019).

The hydroalcoholic extract of dry leaves at concentrations of $50 \mathrm{mg} / \mathrm{ml}$ and $100 \mathrm{mg} / \mathrm{ml}$ was also able to inhibit the growth of Pseudomonas aeruginosa (Sreelakshmy \& Thangapandiyan, 2019), Shigella bayedir (Ismayil \& Nimila, 2019), Aspergillus niger, Bacillus subtilis and Staphylococcus aureus, and its effect was compared to that of the standard drugs tested: Ampicilline trihydrate and Amphoterecine B (Majee et al., 2013). In the study by Bhatt \& Negi (2012), the acetonic extract of the leaves showed superior activity to the ethyl acetate extract against the pathogens of food origin: Bacillus cereus, Escherichia coli, Staphylococcus aureus and Yersinia enterocolitica.

In the study by Bhatt et al. (2013) with methanolic extract, the action of this species was proven against pathogens present in food infections such as: Y. enterocolitica, E. coli, S. aureus and B. cereus. Years later, Shubha \& Bhatt (2015) published research on the prebiotic effect of the aqueous extract proving the ability of this extract to stimulate the growth of Lactobacillus plantarum. This probiotic bacterium consumed the constituents of the extract to produce metabolic enzymes, thus stimulating its growth. Still in this study, the extract inhibited the growth of pathogens (E. coli and Salmonella typhimurium), proving the popular use of this species as an antidiarrheal in foodborne infections.

Extracts and $\mathrm{OE}$ of this species were tested to analyse its viability as an anti-biofilm. There are studies that describe the property of nanoparticles, synthesized from the aqueous extract of its leaves treated with zinc nitrate solution, being able to inhibit biofilm formation of methicillin-resistant Staphylococcus aureus (Vijayakumar et al., 2015). In the study of efficacy against Streptococcus pyogenes biofilms, the methanolic extract of the leaves also showed inhibitory effect functioning as antibiofilm (Manimekalai et al., 2016; Zhang et al., 2017). The OE tested on oxacillin- and vancomycin-resistant S. aureus species also worked as a viable alternative against these biofilms (Vasconcelos et al., 2017).

The OE extracted also showed activity against enteric pathogens: diarrhogenic Escherichia coli, Salmonella sp., Shigella sp. and Vibrio sp. in concentrations of $10 \mu \mathrm{g} / \mathrm{ml}$ (Hassani et al., 2012; Sivaranjani et al., 2019).

The leaves of indian borage can be used to treat opportunistic infections in HIV-infected patients, as its OE has an effect against C. albicans and Cryptococcus neoformans (Asiimwe, 2015). There are also reports of OE activity against fungi of the genus Candida: C.albicans, C.parapsilosis and C.tropicalis (EL-Zefzafy et al., 2016; Manjamalai et al., 2012; Santos et al., 2016; Vijayakumar et al., 2015). 


\subsubsection{Antioxidant, anti-inflammatory and analgesic activities}

In twelve articles, results showed antioxidant action, in vitro, of the leaves, roots and stems of this species. In most of these studies, the use of hydroalcoholic leaves extract showed better activity when compared to other types of solvents (Amarasiri et al., 2018; Bezerra et al., 2017; Bhatt \& Negi, 2012; Bhatt et al., 2013; Bole \& Kumudini, 2014; El-hawary et al., 2012; Haryani et al., 2018; Hasibuan et al., 2013; Patel et al., 2010a; Prasenjit et al., 2011). In the comparative study carried out by Bhatt \& Negi (2012) with different types of solvents: hexane, acetone, ethyl acetate metanol and hydroalcohol, a greater antioxidant activity was detected in the ethyl acetate extract of the leaves, followed by the acetonic extract.

Seven articles reported anti-inflammatory activity, with aqueous, ethanolic extracts and/or OE. The anti-inflammatory activity of the ethanolic extract of the leaves proved to be excellent when compared to indomethacin and hydrocortisone, while the essential oil showed anti-inflammatory activity similar to diclofenac sodium (standard drugs tested) (Devi \& Periyanayagam, 2010; El-hawary et al., 2012; Manjamalai et al., 2012).

There are records of the use of aqueous extract to inhibit pain induced by acetic acid and formalin and inflammation induced by carrageenan. It was found that this effect was related to the amount of carvacrol in the aqueous extract, resulting in the modulation of antioxidant enzymes in the liver, leading to a decrease in malondialdehyde, tumor necrosis factor alpha (TNF- $\alpha$ ) and cyclooxygenase 2 (COX-2) production of paw edema in rats (Akinbo et al., 2018; Chiu et al., 2012; Leu et al., 2019). Thymoquinone was detected in the hexanic fraction of leaves as a compound that inhibits the expression of TNF- $\alpha$ (Chen et al., 2014).

Recent studies report that the constituents rosmarinic acid, cirsimaritin, salvigenin and carvacrol are correlated with the inhibition of inflammasome and activation of inflammatory responses, with an inhibitory activity observed in NLRP3 inflammasome blockade (Leu et al., 2019).

Three articles were found that prove analgesic activity: Chiu et al., 2012; El-Hawary et al., 2012 and Majee et al., 2013. In two studies, indomethacin was the standard drug used, and for El-Hawary et al. (2012), the best response was in alcoholic extracts and ethyl acetate fractions of the leaves while for Chiu et al. (2012) the best response was in the aqueous extract. In the study by Majee et al., 2013, using pentazocine as the standard drug, the analgesic effect was confirmed in the hydroalcoholic extract of the leaves. These records scientifically prove its popular use in pain relief.

\subsubsection{Anticarcinogenic activity}

Eight research papers identified anticarcinogenic activity (Bhatt et al., 2013; Hasibuan \& Rosidah, 2015; Hasibuan \& Sumaiyah, 2019; Hasibuan et al., 2013; Hasibuan et al., 2015; Rosidah \& Hasibuan, 2014; Thirugnanasampandan et al., 2015; Yulianto et al., 2017).

In Bhatt et al. (2013) the sample extracted in methanol presented as constituents: total phenols, flavonoids and condensed tannins in greater proportions when compared to the others. Cytotoxic activity against cervical adenocarcinoma cells (HeLa) was detected in the hexane and alcoholic leaves extracts (Hasibuan et al., 2013; Hasibuan \& Rosidah, 2015). In the study by Hasibuan et al. (2013) the ethyl acetate extract showed the highest content of phenolic compound and the best antioxidant and anticancer response.The ethanolic extract was transformed into nanoparticles by gelation, to test its cytotoxicity against HeLa, MCF-7 and T47D cells in vitro. There are also records of studies showing synergism with doxorubicin in ethyl acetate extract to inhibit metastasis in T47D breast cancer cells (Hasibuan et al., 2015; Rosidah \& Hasibuan, 2014).

There are also reports of the anticarcinogenic potential, with application of nanoparticles of the ethanolic extract to improve bioavailability in the investigation of antiproliferative and pro-apoptosis effects in T47D breast cancer cell lines, as well as studies with essential oil in colorectal cancer cell lines (HT-29). It was found that OE can be a protector of DNA 
damage in 3T3-L1 fibroblast cells, depending on the applied concentration (Hasibuan \& Sumaiyah, 2019; Thirugnanasampandan et al., 2015).

\subsubsection{Diuretic e nephroprotective activities}

The diuretic and nephroprotective activities of the ethanolic extract of the leaves were tested using furosemide as a standard drug in nephropathies induced acetaminophen. The research showed an increase in the total production of urine and urinary electrolytes, proving the nephroprotective and antioxidant effects (Palani et al., 2010).

The studies by Amarasiri et al. (2018), El-hawary et al. (2012) and Patel et al. (2010b) evaluating the nephroprotective and diuretic effects of aqueous and ethanolic leaves extracts also showed a significant increase in urinary volume and urinary electrolytes. Analyses with alcoholic leaves extract showed promising results in cisplatin-induced nephropathies, suggesting that the extract increases the expression of TGF-1 $\beta$ (transforming growth factor-1 $\beta$ ) and, consequently, inhibits renal necrosis and cellular infiltration (Sahrial \& Solfaine, 2019).

\subsubsection{Larvicidal, antileishmania e anthelmintic activities}

Three articles demonstrated the larvicidal activity of the OE extracted from leaves against Anopheles stephensi (mosquito vector of malaria), Culex quinquefasciatus and larvae of Aedes aegypti. The main phytochemical constituents identified in these studies were carvacrol (28.65\%), thymol (21.66\%), undecanal (8.29\%), $\gamma$-terpinene (7.76\%), $\rho$-cymene (6.46\%), caryophyllene oxide (5.85\%), $\alpha$-terpineol (3.28\%) and $\beta$-selinene (2.01\%) (Arjunan et al., 2012; Senthilkumar \& Venkatesalu, 2010; Vijayakumar et al., 2015).

The larvicidal test determined the $\mathrm{LC}_{50}$ (Lethal Concentration - LC) of the OE at $33.54 \mathrm{ppm}($ after $12 \mathrm{~h}$ ) and 28.37 ppm (after $24 \mathrm{~h}$ ), while for $\mathrm{LC}_{90}$ the observed values were $70.27 \mathrm{ppm}$ (after $12 \mathrm{~h}$ ) and $59.38 \mathrm{ppm}$ (after $24 \mathrm{~h}$ ). The results showed that the OE obtained from leaves is an inexpensive and ecological source of natural larvicidal agent that can be used to control and reduce the population of malaria vector mosquitoes, since there are records of drug resistance among these parasites (Arjunan et al., 2012; Senthilkumar \& Venkatesalu, 2010).

The extract was mixed with a solution of zinc nitrate and submitted to the drying process until obtaining the nanoparticles, which showed safe and satisfactory results against A. stephensi, C. quinquefasciatus and C. tritaeniorhynchus. In this proposal, a formulation was developed to achieve better selectivity and less side effects (Vijayakumar_et al., 2015).

Regarding antileishmania activity, two articles described this action in the essential oil, in vitro and in vivo, against Leishmania (Viannia) braziliensis. The OE presented antileishmania activity in tests in vitro and in vivo. The oil inhibited the growth in vitro of 107 promastigotes of Leishmania braziliensis after 48 hours, by intralesional administration for 14 days. The ethyl acetate extract from leaves also caused an in vitro and in vivo reduction in the number of promastigotes, in a shorter treatment time, and can be an additive to the existing therapy (Gonçalves, 2017; Lima et al., 2014).

Alcoholic extracts from leaves, roots and stems showed good anthelmintic activity against Pheritima posthuma (intestinal parasite). The response was close to the control drugs used in the study, piperazine citrate and albendazole, with the most potent action attributed to the leaves extract and the least potent to the root extract (Prasenjit et al., 2011).

\subsubsection{Other identified actions}

The improvement of animal feed with the addition of indian borage leaves to obtain weight gain in domestic chickens, are applications for veterinary use. The lowest amount of total coliforms and CFU (colony-forming units) detected in the feces of these birds, was observed in the group with antibiotic-free diet, which were replaced by the leaves extract. Therefore, this 
study proves the bacteriostatic efficiency of the leaves extract, reducing the bacterial count in the feces and indicating a safe alternative to replace antibiotics in poultry feed (Chuchuca et al., 2016).

Another reported veterinary use is of leaves used in vitro as a modulator of rumen fermentation. The addition of leaves to the diet can reduce methane generation by up to $30 \%$ and increase the digestion of dry matter, ammonia and other fermentation substances, such as volatile fatty acids, whose isomers are beneficial for human health (Yanza et al., 2018).

The study of psoriasis reports an ointment formulation made from ethanolic extract of roots. The antipsoriasis effect was proven to induce psoriasis with topical application of a mixture containing formaldehyde for seven days on the dorsal skin of mice. The effect of ointments containing indian borage extract at concentrations of $0.5 \%$ and $1 \%$, was evaluated by the severity index of psoriasis, its phenotypic characteristics such as redness, scales and erythema and the aspects of the epidermal layer of the skin in vivo. There was a progressive reduction in the severity of psoriasis lesions, showing good response to its treatment and confirming its traditional use in skin diseases (Vijayalakshmi et al., 2019).

The hepatoprotective effects of the ethanolic and aqueous extract from leaf were tested to induce hepatotoxicity in rats with carbon tetrachloride (CCl4). Animals with altered liver function in this research were monitored using biochemical markers (aspartate transaminase, alanine transaminase, alkaline phosphatase, gamma-glutamyl transpeptidase and total and direct bilirubin), and those treated with ethanol extract showed more effective recovery of these markers, in compared to those treated with the aqueous extract. And once the hepatocytes have regenerated and the fat changes have normalized, validating the popular use of this species due to its hepatoprotective effect (Patel, 2011).

The antidiabetic activity, in ethanol and acetone extracts of leaves, by alpha-amylase inhibition was confirmed in vitro (Bole \& Kumudini, 2014). Therapeutic applications of this species can expand its use as a functional nutraceutical food (Bhatt et al., 2013).

This study synthesized the existing knowledge in scientific publications about $P$. amboinicus and its therapeutic properties, as well as identified the existing processes and products involving this species and its applications in order to stimulate innovations in biotechnology.

This prospecting revealed that the benefits of this species can be seen in both humans and animals, with different purposes. The scientific publications analyzed showed that some therapeutic actions of popular use, although tested and validated, are not yet described in patent documents. The good therapeutic performance of this plant contributes to future studies where the information provided here can be used for the developing of innovative products.

\section{Conclusions}

There was an interdependence between the information found in patent databases and academic research about $P$. amboinicus and its therapeutic actions. And the association of technology with scientific research is essential to validate the traditional use of this species by the population.

These data can leverage research for the generation of pharmaceutical patents, be they process or product patent and the development of products with cosmetic or food applications. Therefore, studies are promising due to the many potentialities of this plant that have not yet been fully elucidated and explored.

\section{Acknowledgments}

This work was carried out with support from the Coordination for the Improvement of Higher Education Personnel Brazil (CAPES) - Funding Code 001, National Council for Scientific and Technological Development (CNPq) and Maranhão State Research Support Foundation (FAPEMA). The authors also thank the Graduate Program in Biotechnology (RENORBIO) 
and the Federal University of Maranhão (UFMA) for the support and infrastructure provided for research, analysis and data discussion.

\section{References}

Akinbo, D. B., Onyeaghala, A. A., Emomidue, J. O., Ogbhemhe, S. O., \& Okpoli, H. C. (2018). Phytochemical and anti-inflammatory activities of aqueous leaves extract of indian borage (oregano) on rats induced with inflammation. Cancer Biomark. 22 (2), 257-265. https://dx.doi.org/10.3233/CBM-170893.

Amarasiri, A. M. S. S., Attanayake, A. P., Jayatilaka, K. A. P. W., \& Mudduwa, L. K. B. (2018). Acute nephroprotective and antioxidant activities of aqueous leaves extract of Plectranthus amboinicus (Roxb.) grown in Sri Lanka. J. Pharmacogn. Phytochem. 7 (4), 155-161. http://dx.doi.org/10.22271/phyto

Amparo, K. K. S., Ribeiro, M. C. O., \& Guarineiro, L. L. N. (2012). Estudo de caso utilizando mapeamento de prospecção tecnológica como principal ferramenta de busca científica. Perspect. Ciênc. Inf. 17 (4), 195-209. https://doi.org/10.1590/S1413-99362012000400012

Arjunan, N., Murugan, K., Madhiyazhagan, P., Kovendan, K., Prasannakumar, K., Thangamani, S., \& Barnard, D.R. (2012). Mosquitocidal and water purification properties of Cynodon dactylon, Aloe vera, Hemidesmus indicus and Coleus amboinicus leaves extracts against the mosquito vectors. Parasitol. Res. 110 (4), 1435-1443. https://dx.doi.org/10.1007/s00436-011-2646-3

Arumugam, G., Swamy, M. K., \& Sinniah, U. R. (2016). Plectranthus amboinicus (Lour.) Spreng.: botanical, phytochemical, pharmacological and nutritional significance. Molecules. 21 (4), 1-26. https://dx.doi.org/10.3390/molecules-21040369

Asiimwe, S. (2015). Nutri-medicinal plants used in the management of HIV/AIDS opportunistic infections in Western Uganda: documentation, phytochemistry and bioactivity evaluation. [Doctoral dissertation, KTH Royal Institute of Technology]. Universites service US-AB Stockholm: Uganda. https://www.diva-portal.org/smash/record.jsf?pid=diva2\%3A854066\&dswid=1641

Bezerra, R. D. C. F., de Oliveira Neto, F. B., da Silva, F. F. M., Bertini, L. M., \& Alves, L.A. (2017). Seasonal effect in essential oil composition and antioxidant activity of Plectranthus amboinicus leaves. Biosci. J. 33 (6), 1608-1616. https://doi.org/10.14393/BJ-v33n6a2017-37154.

Bhatt, P., \& Negi, P. S. (2012). Antioxidant and antibacterial activities in the leaves extracts of indian borage (Plectranthus amboinicus). Food Nutr. Sci. 3, 146-152. http://dx.doi.org/10.4236/fns.2012.32022

Bhatt, P., Joseph, G. S., Negi, P. S., \& Varadaraj, M. C. (2013). Chemical composition and nutraceutical potential of indian borage (Plectranthus amboinicus) stem extract. J. Chem. 2013. 1-7. https://dx.doi.org/10.1155/2013/320329

Bhatt P; \& Shubha J. R. (2015). Plectranthus amboinicus leaves stimulate growth of probiotic $l$. Plantarum: evidence for ethnobotanical use in diarrhea. J. Ethnopharmacol. 166, 220-227. https://doi.org/10.1016/j.jep.2015.02.055

Bole, S., \& Kumudini, J. (2014). Phytochemical screening and biological activities of medicinal plant Coleus aromaticus. WJPPS. 3 (6), 974-86. https://www.semanticscholar.org/paper/Phytochemical-screening-and-biological-activities-bole/57afa7cc1596203acf5802a41bb187d97ae4812a

Caruso, L. A., \& Tigre, P. B. (2004). Modelo SENAI de prospecção: documento metodológico. Montevideo, CINTERFOR/OIT. https://www.oitcinterfor.org/node/6160

Chen, Y. S., Yu, H. M., Shie, J. J., Cheng, T. J. R., Wu, C. Y., Fang, J. M., \& Wong, C. H. (2014). Chemical constituents of Plectranthus amboinicus and the synthetic analogs possessing anti-inflammatory activity. Bioorg. Med. Chem. 22 (5), 1766-1772. https://dx.doi.org/10.1016/j.bmc.2014.01.009.

Chiu, Y. J., Huang, T. H., Chiu, C. S., Lu, T. C., Chen, Y. W., Peng, W. H., \& Chen, C. Y. (2012). Analgesic and antiinflammatory activities of the aqueous extract from Plectranthus amboinicus (Lour.) Spreng. both in vitro and in vivo. Evid. Based Complement. Alternat. Med. 508137. https://dx.doi.org/10.1155/2012/508137

Chuchuca, C. C., Quinche, Á. R. S., González, O. N. V., Flores, L. S. H., \& Guerrero, J. N. Q. (2016). Use of vinegar and oreganón Plectranthus amboinicus (Lour.) Spreng. infusion for "Acriollados" bred broilers (Gallus gallus domesticus). Acta Agron. 65 (3), 298-303. https://dx.doi.org/10.15446/acag.v65n3.46222

Devi, K. N., \& Periyanayagam, K. (2010). In vitro anti-inflammatory activity of Plectranthus amboinicus (Lour.) Spreng. by HRBC membrane stabilization. Int. $\quad$ J. Pharm. Sci. Res. $\quad$ 26-29. https://www.technicaljournalsonline.com/ijpsr/VOL\%20I/IJPSR\%20VOL\%20I\%20ISSUE\%20I\%20JULY\%20SEPTEMBER\%202010/IJPSR\%20VOL\%20I $\% 20 I S S U E \% 20 I \% 20$ Article\%204.pdf

Dutta, S., Lanvin, B., \& Wunsch-Vincent, S. (2019). Global Innovation Index (GII) 2019: Creating healthy lives-the future of medical innovation. Itaca, Fontainebleau e Genebra: Cornell, INSEAD e OMPI. https://www.wipo.int/publications/en/details.jsp?id=4434

El-Hawary, S. S., El-Sofany, R. H., Abdel-Monem, A. R., Ashour, R. S., \& Sleem, A. A. (2012). Polyphenolics content and biological activity of Plectranthus amboinicus (Lour.) Spreng. growing in Egypt (Lamiaceae). Pharmacogn. J. 4 (32), 45-54. http://dx.doi.org/10.5530/pj.2012.32.9

EL-Zefzafy, M. M., Dawoud, G. T., \& El-Morsy, T. H. (2016). In vitro and in vivo growth, chemical and antimicrobial studies for Plectranthus amboinicus plant. Int. J. PharmTech. Res. 9 (12), 851-865. https://www.semanticscholar.org/paper/In-Vitro-and-In-Vivo-Growth\%2C-Chemical-and-Studies-EL-Zefzafyawoud/7759d616631db27c9c631219b7d26e6e3d5d2b1b

Gonçalves, T. B., Braga, M. A., Oliveira, F. M. de, Santiago, G M. P., Carvalho, C. B. M., Cabral, P. B., Santiago, T. M., Sousa, J. S., Barros, E. B., Nascimento, R. F., \& Nagão-Dias, A. T. (2012). Effect of subinihibitory and inhibitory concentrations of Plectranthus amboinicus (Lour.) Spreng. essential oil on Klebsiella pneumoniae. Phytomedicine. 19 (11), 962-968. https://doi.org/10.1016/j.phymed.2012.05.013. 
Gonçalves, T. B. (2017). Estudo in vitro e in vivo da atividade leishmanicida do extrato acetato de etila de Plectranthus amboinicus (Lour.) Spreng. frente à Leishmania (Viannia) braziliensis. [Doctoral dissertation, Federal of University of Ceara-Brasil]. http://www.repositorio.ufc.br/handle/riufc/40249

Haryani, R., Harahap, U., \& Satria, D. (2018). Cytoprotective activity of ethanol fraction of Coleus amboinicus Lour. leaves against vero cells induced by $\mathrm{H}_{2} \mathrm{O}_{2}$. Asian J. Pharm. Clin. Res. 11 (1): 28-30. https://dx.doi.org/10.22159/APJCP.2018.v11s1.26559

Hasibuan, P. A. Z., Chrestella, J., \& Satria, D. (2015). Combination effect of ethylacetate extracts of Plectranthus amboinicus (Lour.) Spreng. with doxorubicin against T47D breast cancer cells. Int. J. Pharm. Sci. 7 (10), 156-159. http://repository.usu.ac.id/handle/123456789/63699

Hasibuan, P. A. Z., Rosidah, I. S., \& Nasution, M. P. (2013). Antioxidant and cytotoxic activities of Plectranthus amboinicus (Lour.) Spreng. extracts. IJPTP. 4 (3), 755-758. https://www.iomcworld.org/abstract/antioxidant-and-cytotoxic-activities-of-plectranthus-amboinicus-lour-spreng-extracts-43935.html

Hasibuan, P. A. Z., \& Rosidah, R. (2015). Combination effect of n-hexane extract of Plectranthus amboinicus (Lour.) Spreng. with doxorubicin against HeLa cell lines. ISCC. 6 (3), 111-115. https://dx.doi.org/10.14499/indonesianjcanchemoprev6iss3pp111-115

Hasibuan, P. A. Z., \& Sumaiyah, S. (2019). The anti-proliferative and pro-apoptotic properties of ethanol Plectranthus amboinicus (Lour.) Spreng. leaves ethanolic extract nanoparticles on T47D cell lines. Asian Pac. J. Cancer Prev. 20 (3), 897-901. https://doi.org/10.31557/APJCP.2019.20.3.897

Hassani, M., Saïd, Zainati, I., Zrira, S., Mahdi, S., \& Oukessou, M. (2012). Chemical composition and antimicrobial activity of Plectranthus amboinicus (Lour.) Spreng. essential oil from archipelago of Comoros. J. Essent. Oil-Bear Plants. 15, 637-644. https://doi.org/10.1080/0972060X.2012.10644098

Ismayil, S., \& Nimila, P. J. (2019). Antimicrobial activity of Plectranthus amboinicus (Lour.) against gram-negative bacteria klebsiella pneumoniae and Shigella flexneri and their phytochemical tests. Int. J. Health Sci. Res. 9 (5), 304-311. https://www.ijhsr.org/IJHSR_Vol.9_Issue.5_May2019/45.pdf

León Méndez, G., Fortich, O., del Rosario, M., Torrenegra, M. E., \& González, J. G. (2015). Extracción, caracterización y actividad antioxidante del aceite esencial de Plectranthus amboinicus L. Rev. Cuba. de Farm. 49 (4), 708-718. http://scielo.sld.cu/scielo.php?script=sci_arttext\&pid=S003475152015000400011

Leu, W. J., Chen, J. C., \& Guh, J. H. (2019). Extract from Plectranthus amboinicus inhibit maturation and release of interleukin 1 $\beta$ through inhibition of NF$\kappa \mathrm{B}$ nuclear translocation and NLRP3 inflammasome activation. Front. Pharmacol. 10, 1-12. https://doi.org/10.3389/fphar.2019.00573

Lima, S. C. G., Teixeira, M. J., Lopes Júnior, J. E. G., de Morais, S. M., Torres, A. F., Braga, M. A., Rodrigues, R. O., Santiago, G. M. P., Martins, A. C., \& Nagão-Dias, A. T. (2014). In vitro and in vivo leishmanicidal activity of Astronium fraxinifolium (Schott) and Plectranthus amboinicus (Lour.) Spreng. against Leishmania (Viannia) braziliensis. Biomed. Res. Int. 2014, 1-7. https://dx.doi.org/10.1155/2014/848

Majee, C., Das, G. K., Mazumder, R., \& Chakraborthy, G. S. (2013). Evaluation of analgesic and antimicrobial potential of hydroalcoholic extract of leaves of Coleus aromaticus in albino mice. J. Phytopharmacol. 2 (3), 18-25. https://dx.doi.org/10.31254/phyto

Manimekalai, K., Srinivasan, P., Dineshbabu, J., Guna, G., \& Darsini, D. T. P. (2016). Anti-biofilm efficacy of Plectranthus amboinicus against Streptococcus

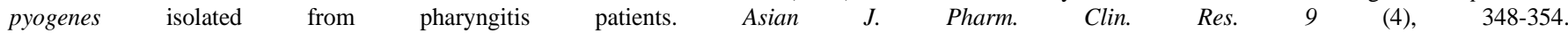
https://innovareaademics.org/journals/index.php/ajpcr/article/download/12337/5862.

Manjamalai, A., Alexander, T., \& Grace, V. B. (2012). Bioactive evaluation of the essential oil of Plectranthus amboinicus by GC-MS analysis and its role as a drug for microbial infections and inflammation. Int. J. Pharm. Sci. 4 (3), 205-211. https://innovareacademics.in/journals/index.php/ijpps

Manojkanna, K. Chandana, C. S., Gayathri, R., Priya, V. V., \& Geetha, R. (2017). Synthesis and characterization of silver nano particles from Plectranthus ambionicus extract and its antimicrobial activity against Enterococcus faecalis and Candida albicans. J. Pharm. Sci. \& Res. 9 (12), $2423-2425$. https://www.jpsr.pharmainfo.in/Documents/Volumes/vol9Issue12/jpsr09121723.pdf

Manojkanna, K., Nasim, I., Gayathri, R., \& Priya, V. V. (2019). Synthesis and characterization of silver nanoparticles from Plectranthus amboinicus extract and its antimicrobial activity against Streptococcus mutans, Lactobacillus. DIT. 12 (6), 1236-1238. https://jprsolutions.info/article_detail.php?article_id=3666

Oliveira, M. M. M., \& Quental, C. M. (2012). The technology foresight as a strategic planning tool for the future construction of the Oswaldo Cruz Institute. RECIIS. 6 (1), 50-61. https://www.reciis.icict.fiocruz.br/index.php/reciis

Oliveira, F. F. M., Torres, A. F., Gonçalves, T. B., Santiago, G. M. P., de Carvalho, C. B. M., Aguiar, M. B., \& Nagão-Dias, A. T. (2013). Efficacy of Plectranthus amboinicus (Lour.) Spreng. in a murine model of methicillin-resistant Staphylococcus aureus skin abscesses. Evid. Based. Complement. Alternat. Med. 2013, 1-9. https://dx.doi.org/10.1155/2013/291592

Palani, S., Raja, S., Naresh, R., \& Kumar, B. S. (2010). Evaluation of nephroprotective, diuretic, and antioxidant activities of Plectranthus amboinicus on acetaminophen-induced nephrotoxic rats. Toxicol. Mech. Method. 20 (4), 213-221. https://doi.org/10.3109/15376511003736787

Patel, R. D., Mahobia, N. K., Singh, M. P., Singh, A., Sheikh, N. W., Alam, G., \& Singh, S. K. (2010a). Antioxidant potential of leaves of Plectranthus amboinicus (Lour.) Spreng. Pharm. Lett. 2 (4), 240-245. . https://www.scholarsresearchlibrary.com/abstract/antioxidant-potential-of-leaves-of-plectranthusamboinicus-lourrnspreng-4809.html

Patel, R., Mahobia, N. K., Gendle, R., Kaushik, B., \& Singh, S. K. (2010b). Diuretic activity of leaves of Plectranthus amboinicus (Lour.) Spreng. in male albino rats. Pharmacogn. Res. 2 (2), 86. https://doi.org/10.4103/0974-8490.62956

Patel, R. (2011). Hepatoprotective effects of Plectranthus amboinicus (Lour.) Spreng. against carbon tetrachloride-induced hepatotoxicity. J. Nat. Pharm. 2 (1), 28-35. https://doi.org/10.4103/2229-5119.78495

Prasenjit, B., Hullatti, K. K., \& Vijay, K. M. L. (2011). Anthelmintic and antioxidant activity of alcoholic extracts of different parts of Coleus amboinicus Lour. Int. J. Res. Ayurveda. Pharm. 1 (1), 181-185. https://ijrap.net/index.php/login/abstractt?id=386 
Rosidah, \& Hasibuan, P. A. Z. (2014). Cytotoxic effect of n-hexane, ethylacetate and ethanol extracts of Plectranthus amboinícus (Lour.) Spreng. on hela and vero cells lines. IJPRIF. 6 (6), 1806-1809. https://citeseerx.ist.psu.edu/viewdoc/download?doi=10.1.1.1089.5078\&rep=rep1\&type=pdf

Ruan, T. Z., Kao, C. L., Hsieh, Y. L., Li, H. T., \& Chen, C. Y. (2019). Chemical constituents of the leaves of Plectranthus amboinicus. Chem. Nat. Compd. 55 (1), 124-126. https://doi.org/10.1007/s10600-019-02631-9

Sahrial, I., \& Solfaine, R. (2019). Coleus amboinicus extract increases transforming growth factor-1 $\beta$ expression in wistar rats with cisplatin-induced nephropathy. Vet. World. 12 (8), 1346-1351. https://doi.org/10.14202/vetworld.2019.1346-1351

Santos, F. A., Serra, C. G., Bezerra, R. J., Figueredo, F. G., Matias, F. F., Menezes, I. R., Costa, J. G. M., \& Coutinho, H. D. (2016). Antibacterial activity of Plectranthus amboinicus Lour (Lamiaceae) essential oil against Streptococcus mutans. Eur. J. Integr. $\quad$ Med.8 (3), $293-297$. https://doi.org/10.1016/j.eujim.2015.11.021

Senthilkumar, A., \& Venkatesalu, V. (2010). Chemical composition and larvicidal activity of the essential oil of Plectranthus amboinicus (Lour.) Spreng. against Anopheles stephensi: a malarial vector mosquito. Parasitol. Res. 107 (5), 1275-1278. https://doi.org/10.1007/s00436-010-1996-6

Silveira, R. C. C. P (2005). O cuidado de enfermagem e o cateter de Hickman: a busca de evidências. Acta Paulista de Enfermagem, 18 (3): $276-84$. https://doi.org/10.1590/S0103-21002005000300008.

Sireesha, N., Kumar, D. V., Supriya, E., Suma, C., Hemanth, N., \& Ramanarayana, C. (2017). Antimicrobial Effect of Plectranthus amboinicus and Ocimum tenuiflorum against Mycobacterium tuberculosis. World J. Pharm. Pharm. Sci. 6 (8), 1008-1017. https://doi.org/10.20959/wjpps20178-9674

Sivaranjani, D., Saranraj, P., Manigandan, M., \& Amala, K. (2019). Antimicrobial activity of Plectranthus amboinicus solvent extracts against human pathogenic bacteria and fungi. JDDT. 9 (3), 36-9. https://doi.org/10.22270/jddt.v9i3.2604

Souto-Maior, F. N., De Carvalho, F. L., De Morais, L. C. S. L., Netto S. M., De Sousa, D. P., \& Almeida, R. N. (2011). Anxiolytic-like effects of inhaled linalool oxide in experimental mouse anxiety models. Pharmacol. Biochem. Behav. 100 (2), 259-63. https://doi.org/10.1016/j.pbb.2011.08.029

Souza, M. T., Silva, M. D., \& Carvalho, R. (2010). Revisão integrativa: o que é e como fazer. Einstein (São Paulo), 8 (1), $102-106$. https://dx.doi.org/10.1590/s1679-45082010rw1134

Sreelakshmy, S., \& Thangapandiyan, S. (2019). In vitro antibacterial efficacy of Plectranthus amboinicus mediated silver nanoparticles against urinary tract pathogens in vitro. Asian J. Pharm. Clin. Res. 12 (2), 153-159. https://doi.org/10.22159/ajpcr.2019.v12i2.28079

Thirugnanasampandan, R., Ramya, G., Gogulramnath, M., Jayakumar, R., \& Kanthimathi, M. S. (2015). Evaluation of cytotoxic, DNA protecting and LPS induced MMP-9 down regulation activities of Plectranthus amboinicus (Lour) Spreng. essential oil. Pharmacogn. J. 7 (1), 32-36. https://doi.org/10.5530/pj.2015.7.3

Vasconcelos, S. E. C. B., Melo, H. M., Cavalcante, T. T. A., Júnior, F. E. A. C., de Carvalho, M. G., Menezes, F. G. R., Sousa, O. V. de, \& Costa, R. A. (2017). Plectranthus amboinicus essential oil and carvacrol bioactive against planktonic and biofilm of oxacillin-and vancomycin-resistant Staphylococcus aureus. BMC Complement. Altern. Med. 17 (1), 462. https://doi.org/10.1186/s12906-017-1968-9

Vijayakumar, S., Vinoj, G., Malaikozhundan, B., Shanthi, S., \& Vaseeharan, B. (2015). Plectranthus amboinicus leaves extract mediated synthesis of zinc oxide nanoparticles and its control of methicillin resistant Staphylococcus aureus biofilm and blood sucking mosquito larvae. Spectrochim. Acta A. Mol. Biomol. Spectrosc. 18 (3), 886-891. https://doi.org/10.1016/j.saa.2014.08.064.

Vijayalakshmi, A., Priyanka, M., Priyadharshini, S., Kumar, S., Jayakumari, S., \& Ravichandiran, V. (2019). Evaluation of herbal ointment containing ethanol extract of Plectranthus amboinicus root for the management of psoriasis. Indian J. Tradit. Know. 18 (3), 553-559. http://op.niscair.res.in/index.php/IJTK/article/view/26743

Zhang, B., Wijesundara, N. M., Abbey, L., \& Rupasinghe, H. V. (2017). Growing medium amendments effect on growth, secondary metabolites and antistreptococcal activity of two species of Plectranthus. J. Appl. Res. Med. Aromat. Plants. 5, 53-59. https://doi.org/10.1016/j.jarmap.2016.11.001

Yanza, Y. R., Szumacher-Strabel, M., Bryszak, M., Gao, M., Kolodziejski, P., Stochmal, A., Slusarczyk, S., Patra, A.K., \& Cieslak, A. (2018). Coleus amboinicus (Lour.) leaves as a modulator of ruminal methanogenesis and biohydrogenation in vitro. J. Anim. Sci. 96 (11), $4868-4881$. https://doi.org/10.1093/jas/sky321

Yulianto, W., Andarwulan, N., Giriwono, P. E., \& Pamungkas, J. (2017). Bioactive compounds from torbangun Plectranthus amboinicus (Lour.) Spreng. chloroform fraction induce apoptosis in breast cancer (MCF-7 cells) in vitro. Trad. Med. J. 22 (1), 37-44. https://doi.org/10.22146/tradmedj.24312 